\title{
PELATIHAN INOVASI DAN PENGEMBANGAN PRODUK PATERA ECO PRINT PALEMBANG
}

\author{
Husni Mubarat ${ }^{1)}$, Heri Iswandi'), Muhsin Ilhaq2) \\ 1)Desain Komunikasi Visual, Fakultas IImu Pemerintahan dan Budaya, Universitas Indo Global Mandiri, Kota \\ Palembang, Provinsi Sumatera Selatan, Indonesia \\ ${ }^{3)}$ Pendidikan Seni Pertunjukan, Fakultas Keguruan dan IImu Pendidikan, Universitas PGRI, Kota Palembang, Provinsi \\ Sumatera Selatan, Indonesia \\ Corresponding author: Husni Mubarat \\ E-mail : husni_dkv@uigm.ac.id
}

Diterima 14 Maret 2021, Direvisi 10 April 2021, Disetujui 10 April 2021

\begin{abstract}
ABSTRAK
Patera Eco Print sebagai mitra sasaran dalam implementasi program Pengabdian Kepada Masyarakat (PKM) yang bergerak di bidang ekonomi produktif memiliki beberapa permasalahan, yaitu belum adanya inovasi produk dan pengembangan desain baik dari segi eksplorasi bentuk, pengembangan jenis produk, maupun eksplorasi pola-pola motif daun yang ditata pada media kain tersebut. Adapun solusi yang ditawarkan sebagai pemecahan permasalahan tersebut, diantaranya adalah inovasi produk Patera Eco Print, pengembangan desain dan jenis-jenis produk. Adapun tujuan utama dari kegiatan ini adalah memberikan ilmu pengetahuan keterampilan tentang cara pengembangan desain produk ecoprint, seperti totebag dan tas laptop. Metode yang digunakan pada Pengabdian ini diantaranya adalah metode survei, dokumentasi, wawancara, pelatihan, sosialisasi dan evaluasi. Adapun capaian dari kegiatan ini yakni diharapkan mitra pelatihan ini dapat mengembangkan desain produk usaha Eco Print, seperti pengembangan desain totebag, tas laptop dan baju dengan demikian capaian ini dapat memperluas jangkauan pasar produk Patera Eco Print.
\end{abstract}

Kata kunci: patera eco print; desain produk; inovasi.

\begin{abstract}
Patera Eco Print as a target partner in the implementation of the Community Service program (PKM) which is engaged in the productive economy has several problems, namely the absence of product innovation and design development both in terms of exploration of forms, development of product types, and exploration of leaf motif patterns. which is arranged on the cloth media. The solutions offered to solve these problems include product innovation Patera Eco Print, design development and product types. The main purpose of this activity is to provide knowledge of skills on how to develop ecoprint product designs, such as tote bags and laptop bags. The methods used in this Community Service include survey methods, documentation, interviews, training, socialization and evaluation. The product output that will be achieved is to create innovative products, such as the development of designs for clothes, jackets and invitation bags, especially in the composition of the motives. The achievement of this activity is that it is hoped that this training partner can develop the design of Eco Print business products. In addition, the product output that will be achieved is the development of product types, such as laptop bags, tote bags, and shirts, such as the development of tote bag designs, laptop bags and clothes, thus this achievement can expand the market reach of Patera Eco Print products.
\end{abstract}

Keywords: patera eco print; product design; innovation.

\section{PENDAHULUAN}

Kerajinan tekstil adalah salah satu kerajinan yang cukup berkembang di Indonesia. Kerajinan tekstil mencakup kerajinan songket, tenun, batik, jumputan, eco print, dan lain sebagainya. Di Indonesia, kerajinan tekstil setiap daerahnya memiliki corak dan ciri khasnya sendiri, terutama pada aspek ragam hias yang pada umumnya dipengaruhi oleh budaya, tradisi dan alam. Bila diamati secara saksama, kerajinan tekstil selalu tumbuh dan berkembang seiring dengan kemajuan zaman.

Salah satu teknik yang berkembang pada kerajinan tekstil adalah ecoprint. Menurut (Herlina et al., 2018) bahwa:

"Teknik eco printing diartikan sebagai suatu proses untuk mentransfer warna dan bentuk ke kain melalui kontak langsung (Flint, 2008). Flint mengaplikasikan teknik ini den-gan 
cara menempelkan tanaman yang memi-liki pigmen warna ke kain, menggulung dan mengikatnya, kemudian direbus di dalam kuali besar. Eksplorasi eco printing bertujuan untuk memperoleh kemungkinankemungkinan visu-al baru yang akan diaplikasikan pada produk fesyen".

Di Kota Palembang sendiri eco print cukup banyak diminati oleh para pengrajin terutama ibu-ibu rumah tangga, karena teknik ini dapat dikatakan tidak terlalu membutuhkan kemampuan teknik yang mumpuni seperti halnya pengerjaan songket, batik, dan tenun yang memang membutuhkan skill dalam proses produksinya. Salah satu pengrajin yang produktif di bidang kerajinan eco print adalah Patera Eco Print. Usaha ini dirintis oleh Rasmini pada tanggal 10 April 2018. Lokasi usaha kerajinan Patera Eco Print berada di Jln. Prajurit Kemas Ali, No. 3089, Rt. 29, Kec. Ilir Timur II Kota Palembang Provinsi Sumatera Selatan.

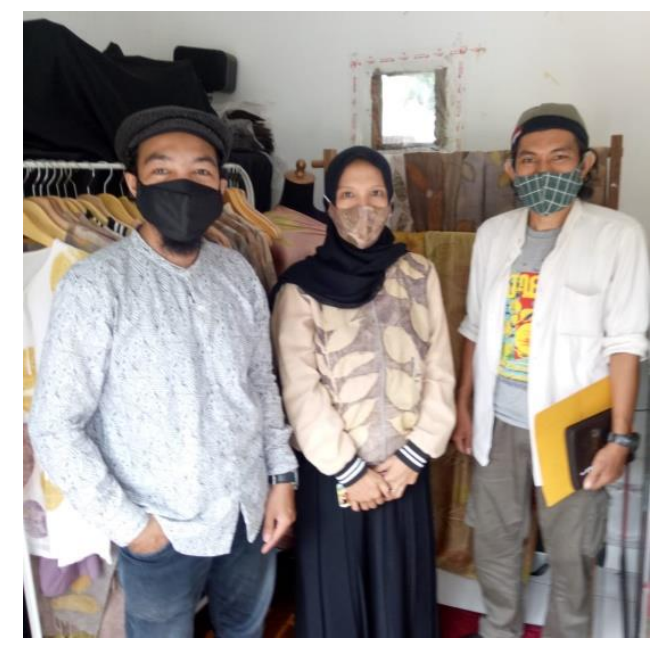

Gambar 1. Survei dan Wawancara bersama Rasmini, pengrajin Patera Eco Print (foto : Muhsin Ilhaq, 2020)

Menurut keterangan Rasmini dalam wawancara pada tanggal 14-10-2020, beberapa alasan ketertarikannya terhadap usaha eco print di antaranya adalah, teknik pengerjaannya yang lebih sederhana dibandingkan dengan pengerjaan songket dan tenun. Aplikasi tekniknya yang sederhana juga dapat diaplikasikan terhadap berbagai produk fashion, seperti baju stelan, tas, jilbab dan lain sebagainya. Di samping itu, teknik eco print juga lebih ramah dengan lingkungan, dimana limbah-limbahnya tidak mencemari lingkungan sehingga tidak membutuhkan tempat produksi secara khusus untuk pembuangan limbahnya. Dari segi pasar, usaha eco print juga memiliki peluang pasar yang banyak diminati oleh masyarakat, terutama kaum perempuan, serta harga yang dapat dijangkau oleh masyarakat menengah dibandingkan dengan songket dan kain jumputan yang ada di Palembang.

Seiring dengan waktu, usaha Patera Eco Print Rasmini selalu berupaya untuk terus eksist dan produktif dalam melahirkan karyakarya kain eco printnya agar dapat bersaing secara kompetitif dengan usaha eco print yang lainnya, baik di tingkat lokal, regional, nasional, maupun internasional. Bila diamati kondisi saat ini, dimana teknologi yang semakin maju dan canggih, tentunya usaha keinginan Rasmini untuk dapat bersaing secara global, tentunya memiliki kesempatan dan peluang mengingat promosi dan pemasaran yang dapat dilakukan secara digital. Tentunya untuk bersaing dibutuhkan karya-karya yang inovatif, menarik dan berkualitas, baik dari segi estetiknya, desainnya, maupun kualitas bahan dan pola eco print yang dirancang sebagai elemen ornamentasi pada media fashion itu sendiri.

Dari awal Patera Eco Print ini dirintis oleh Rasmini, usaha ini sudah memiliki dua orang karyawan tetap yang direkrut dari sekitar Kota Palembang. Selain dua orang karyawan tetap, Rasmini juga memiliki beberapa karyawan yang sifatnya kondisional, manakala pesanan barang atau produk sedang meningkat, Rasmini biasanya mengajak ibu-ibu rumah tangga yang ada di sekitarnya untuk bekerja. Namun, di masa Panndemi Covid 19 saat sekarang ini produksi dan pasaran Patera Eco Print mengalami penurunan hingga $60 \%$. Seiring dengan adanya himbauan pemerintah meningkatkan kembali produktivitas masyarakat dengan New Normal usaha Patera Eco Print mulai melakukan aktivitas produktif, baik dalam produksi maupun menerima pesanan dari konsumen serta mengikuti pameran dan bazar yang difasilitasi oleh pemerintah maupun swasta, seperti mall.

Untuk sistem pemasaran, produk usaha Patera Eco Print dipasarkan melalui sistem konvensional dan online. Sistem konvensional dipasarkan melalui toko langsung (konsumen datang sendiri), selain itu pemasaran secara konvensional juga dilakukan dengan mengikuti pameran dan bazar. Dari wawancara yang dilakukan, rata-rata penjualan produk Patera Eco Print: produk kain rata-rata perbulanya dapat terjual sekitar $4-6$ baju perbulannya, jilbab rata-rata penjualan berkisar 4 buah perharinya, masker rata-rata penjulan perharinya berkisar 5-7, jaket rata penjualannya berkisar 3-5 perbulannya. Sebagian penjualan produk tersebut itu dilakukan melalui bazar dan pameran, sedang melalui media online, sejauh ini hanya sebatas promosi. Untuk omzet dalam hitungan perbulannya Patera Eco Print dapat 
mencapai kisaran Rp. 4.500.000 hingga Rp. 5.000.000.- (omzet ini dihitung sebelum adanya Pandemi Covid 19).

Salah satu permasalahan yang dihadapi Patera Eco Print adalah pengayaan atau pengembangan desain dan inovasi produk. Selama ini produk yang dihadirkan cenderung mengikuti produk-produk yang sudah ada, sehingga konsumen yang sudah berlangganan kadang kala menanyakan adakah inovasi desain-desain yang baru. Selain itu, kendala yang dihadapi adalah pengembangan produkproduk ecoprint yang lain, seperti tas baju kemeja, totebag, selendang, sall, dan termasuk juga produk kerajinan seperti kotak tissue. Pengembangan produk ini tentunya memberikan pengaruh terhadap perluasan pasar bagi usaha Patera Eco Print sendiri, karena tidak jarang yang menyakan jenis-jenis produk tersebut, apalagi ketika kegiatankegiatan pameran dan bazar tentunya semakin banyak produk yang disediakan, maka semakin luas pula pasar yang dapat dijangkau.

Berkaitan dengan inovasi dan pengembangan desain produk Patera Eco Print, adapun aspek yang perlu diperhatikan juga adalah pola motif dedaunan yang disusun pada media kain tersebut. Sejauh ini sebagaimana yang diungkapkan oleh Rasmini, pola penyusunan motif dedaunan tersebut dikomposisikan secara acak, karena untuk dikomposisikan secara terpola ia merasa kurang memiliki pengalaman estetik untuk menciptakan pola-pola yang baru.

"Membangun sebuah komposisi medium rupa yang konstruktif, sistematis dan harmonis bukanlah pekerjaan yang mudah karena sebuah komposisi terbangun dari beberapa unsur visual, serta seniman atau desainerlah yang memilih untuk mereduksi elemen yang ada dalam unsur rupa tersebut" (Hendriyana, 2019).

Dari segi manajemen, terutama pada aspek tata kelola pembukuan keuangan, sejauh ini usaha Patera Eco Print tidak terecord dengan baik, seperti catatan modal, biaya produksi, biaya operasional, keuntungan hingga sistem pengupahan karyawan yang belum terkelola dengan masksimal. Faktor ini juga disebabkan oleh wawasan dan pemahaman yang masih minim dalam manajemen tersebut, walaupun beberapa kali Rasmini sempat mengikuti pelatihan mengenai tata kelola pembukuan keuangan, namun hal itu tidak dapat membantu banyak, karena pelatihan yang sifatnya hanya dalam kurun waktu tertentu, tanpa adanya bimbingan lebih lanjut. Peranan manajemen sesungguhnya sangatlah penting, tidak hanya berkaitan dengan pengelolaan keuangan, namun juga sumber daya yang ada. Menurut (Yahya, 2016) ada tiga unsur manajemen yang sangat esensial, "pertama, sumber daya yang harus diberdayakan (empowering) secara makasimal, yaitu manusia (man), uang (money), peralatan (material) pendekatan atau metode, dan pasar, kedua, pemanfaatan atau pemberdayaan, ketiga adalah tujuan lembaga atau organisasi".

Adapun tujuan pengabdian kepada masyarakat, selain untuk selain untuk menjalankan Tridarma Perguruan Tinggi, kegiatan ini juga bertujuan untuk mentransferkan ilmu pengetahuan dan tekhnologi, khususnya pada aspek ketrampilan desain dan inovasi produk. Oleh karena itu, tim pengabdian berupaya semaksimal mungkin untuk memberikan pelatihan terkait dengan inovasi, pengembangan desain produk, serta sosialisasi tentang manajemen pembukuan yang lebih rapi dan tersusun. Harapannya, pengabdian kepada masyarakat ini dapat menjadikan usaha Patera Eco Print menjadi usaha yang profesional dan dapat berkompetitif, baik dari segi kualitas produk, inovasi produk maupun harga, sehingga mampu meningkatkan omzet dari yang sebelumnya. Di samping itu, usaha Patera Eco Print Rasmini nantinya diharapkan juga mampu menciptakan lapangan pekerjaan bagi ibu-ibu rumah tangga di sekitar, yang selama ini hanya bersifat kondisional. Capaian tersebut bagi tim pengabdian kepada masyarakat dapatlah diukur, hal ini tentunya berdasarkan kompetensi yang dimiliki oleh tim dari berbagai disiplin ilmu, seperti Seni Kriya dan Desain Grafis, sehingga kolaborasi tim ini dapat memberikan dampak yang positif terhadap kemajuan usaha Patera Eco Print Rasmini.

\section{METODE}

Dalam kegiatan Pengabdian Kepada Masyarakat, metode merupakan salah satu bagian yang penting untuk dirumuskan, karena ketepatan metode yang digunakan akan sangat berpengaruh terhadap proses berjalannya kegiatan tersebut. Metode pada dasarnya dapat diartikan sebagai cara, teknik ataupun strategi dalam mencapai suatu tujuan. Metode dapat diartikan sebagai cara, teknik, strategi maupun sistem dan prosedur yang ditempuh untuk mencapai suatu tujuan. Dalam pengertian yang lebih luas metode dianggap sebagai cara-cara, strategi untuk memahami realitas, langkahlangkah sistematis untuk memecahkan rangkaian sebab akibat berikutnya (Nyoman Kutha Ratna, 2010). Pada tahap pelaksanaan kegiatan Implementasi Program Kemitraan Masyarakat; Inovasi dan Pengembangan Desain Produk Patera Eco Print. Kegiatan ini dilakukan di di Jln. Prajurit Kemas Ali, No. 3089, 
Rt. 29, Kec. Ilir Timur II Kota Palembang Provinsi Sumatera Selatan. Kegiatan ini berlangsung dari tanggal 14 Oktober sampai dengan 14 Desember 2020adapun peserta pelatihan yang terlibat dalam kegiatan ini sebanyak 7 orang peserta dari Usaha Patera Eco Print. Metode pelaksanaan yang disusun tidak terlepas dari hasil analisis situasi yang tim lakukan agar metode yang diterapkan dapat mencapai tujuan program ini.

Adapun metode pelaksanaan kegiatan Pengabdian Kepada Masyarakat dengan skema Program Kemitraan Masyarakat dapat disusun sebagai berikut:

1. Metode Survei. metode ini bertujuan untuk mengetahui secara langsung terhadap kondisi dan situasi mitra, baik berkenaan dengan lokasi, tempat produksi, tempat pemasaran, maupun alat, bahan dan jenisjenis produk, dalam hal ini adalah produk fashion Ecoprint. Dengan mengamati secara langsung, tentunya tim akan dapat mengetahui situasi yang ada pada mitra, yaitu Patera Eco Print. Metode survei ini setidaknya dilakukan minimal 2 kali, agar data-data yang dikumpulkan dapat dianalisis secara maksimal sehingga Implementasi Program ini dapat memecahkan masalah secara tepat.

2. Metode Dokumentasi. Metode ini bertujuan untuk memperoleh data visual atau fisik yang ada di lapangan, sehingga data ini dapat dijadikan sebagai bukti keberadaan mitra, seperti kondisi dan situasi mitra itu sendiri.

3. Metode Wawancara. Metode ini dilakukan bersamaan dengan kegiatan survei. Metode wawancara bertujuan untuk mengetahui kondisi dan situasi mitra secara lebih detail, termasuk di dalamnya adalah untuk mengetahui profil usaha Patera Eco Print itu sendiri. Kegiatan wawancara dilakukan dengan mempersiapkan beberapa pokok bahasan berupa pertanyaan yang sesuai dengan panduan dalam skema Program Kemitraan Masyarakat. Data-data yang diperoleh dari hasil wawancara kemudian diolah dan dianalisis. Kesimpulan analisis yang didapatkan dilakukan diskusi kembali bersama mitra yaitu Patera Eco Print, sehingga menemukan kesepakatan program yang akan diimplementasikan nantinya.

4. Metode Pelatihan. Metode ini dilakukan secara langsung oleh tim, terutama berkenaan dengan pelatihan dalam menciptakan inovasi dan pengembangan desain produk. Metode pelatihan juga dilakukan pada aspek cara mengkomposisi dan menata daun-daun menjadi motif yang terpola. Metode ini akan menerapkan ilmu-ilmu desain dan seni rupa, baik dari segi elemen-elemen seni rupa maupun dari segi prinsipnya. Melalui metode ini diharapkan ilmu-ilmu tata rupa dapat ditransfer terhadap mitra, sehingga mitra memiliki pengalaman estetik dan memiliki kemapuan untuk mengekplorasi bentuk dan pola-pola susunan motif pada usaha eco print tersebut.

5. Metode Sosialisasi dan presentasi materi. Adapun sosialisasi yang dilakukan di antaranya berkenaan dengan keilmuan manajemen terutama pada aspek pengelolaan pembukuan keungan. Metode ini juga didukung dengan presentasi materi dari tim pengabdian sebagai nara sumber. Materi-materi yang disajikan nantinya sesuai dengan bidang ilmu dan kompetensi masing-masing dari tim. Sosialisasi dan presentasi materi ini juga termasuk dalam hal bagaimana strategi promosi dan merancang media grafis dalam upaya membangun brand usaha agar citranya dapat dikenali oleh masyarakat sebagai calon konsumen, yang tentunya dapat menciptakan peluang pasar tersendiri, baik di tingkat lokal, regional, nasional maupun internasional.

6. Metode Evaluasi. "Secara Garis besar metode evaluasi dapat dipahami sebagai proses untuk mengukur atau menilai, apakah suatu kegiatan yang dilaksanakan sesuai dengan tujuan yang ingin dicapai" (Mubarat, Husni., 2020) Oleh karenanya, metode ini dilakukan untuk mengukur tingkat keberhasilan dari pada kegiatan yang dilaksanakan, yaitu pengembangan desain dan inovasi produk. Aspek yang tidak kalah penting dari pelaksanaan metode evaluasi ini adalah sebagai media untuk mengukur sejauh mana mitra dalam hal ini Patera Ecoprint mampu mnyerap dan mengimplentasikan IImu Pengetahuan, Teknologi dan Seni (IPTEKS) yang disampaikan oleh narasumber (Tim Pengabdian).

7. Metode Bimbingan. Metode ini tidak hanya dilakukan ketika kegiatan berlangsung, namun juga dilakukan pasca kegiatan, yang mana tim akan selalu terbuka apabila mitra Patera Eco Print membutuhkan bimbingan dan arahan dari tim pengabdian UIGM, tentunya ini merupakan bentuk konsistensi tim dalam melaksanakan kewajiban sebagai bagian dari Tridarma Perguruan Tinggi. Metode ini juga bertujuan sebagai keberlangsungan kerja 
sama dengan mitra untuk pengembangan Pengabdian Hibah Ristek Brin untuk ke depannya.

\section{HASIL DAN PEMBAHASAN}

Hasil kegiatan pengabdian ini merupakan satu rangkaian proses yang dilakukan dengan metode kolaborasi, mulai dari pemetaan terhadap jenis-jenis produk yang dibuat, bahan-bahan dasar kain, bahan pewarnaan alami, hingga pada aspek desain. Dalam kegiatan pengabdian ini tujuan utamanya adalah inovasi dan pengembangan desain produk Patera Eco print. Adapun hasil pengabdian yang dicapai adalah sebagai berikut:

\section{Desain Produk Patera Eco Print}

Keberadaan desain bagi Patera Eco Print memiliki pengaruh yang cukup signifikan terhadap pengembangan suatu produk, baik dari segi jenis produk, maupun dari segi pola dan motif-motif yang diimplementasikan. Melalui pengembangan desain, produk yang dihasilkan memiliki nilai kebaharuan sehingga dapat memberikan bentuk-bentuk yang baru terhadap konsumen. Adapun desain-desain produk yang dikembangkan pada kegiatan ini adalah:

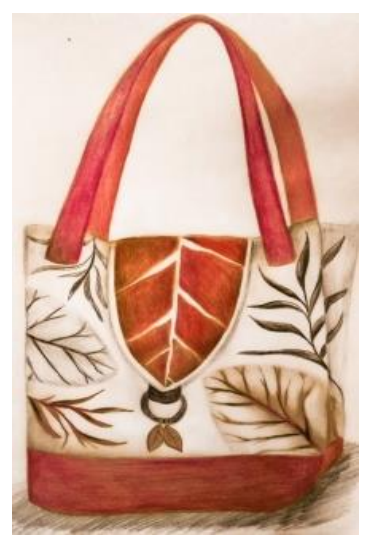

Gambar 2. Desain ini merupakan pengembangan dari desain totebag dengan bahan yang digunakan adalah bahan kain kanvas.

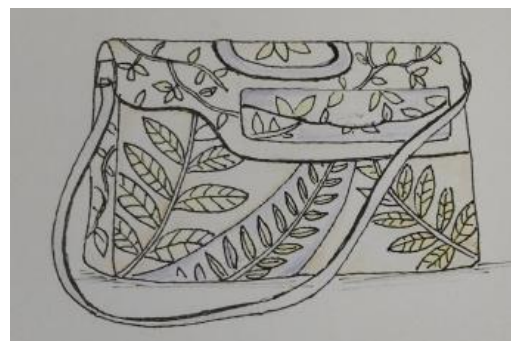

Gambar 3. Desain tas laptop dengan motif sulur daun dibuat dengan bahan kulit.

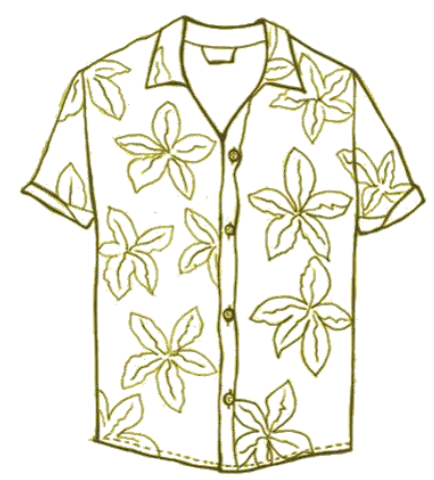

Gambar 4. Desain baju pantai eco print dibuat dengan pola motif daun lanang, di mana pola motifnya ditata dengan keteraturan.

\section{Jenis-Jenis Bahan}

Bahan merupakan salah satu bagian utama dalam proses produksi kain ecoprint. Salah satu jenis bahan dasar dalam pembuatan kerajinan eco print adalah kain dan kulit. Bahan dasar yang digunakan sangat berpegaruh terhadap hasil produksi terutama pada aspek kualitas. Bahan-bahan yang digunakan juga berpengaruh terhadap nilai jual dari produk yang dihasilkan, semakin berkualitas bahan yang digunakan, maka semakin tinggi pula nilai harga produk yang dipasarkan.

Berikut adalah jenis-jenis bahan kain yang digunakan:

Tabel 1. Jenis-Jenis bahan dasar kain yang digunakan oleh Patera Eco print

\begin{tabular}{ll}
\hline $\begin{array}{c}\text { Jenis-Jenis Bahan } \\
\text { Dasar }\end{array}$ & \multicolumn{1}{c}{ Aplikasi Bahan } \\
\hline Kain Sutera & $\begin{array}{l}\text { Baju setelan, jilbab, } \\
\text { masker, } \\
\text { dasaran } \\
\text { bahan }\end{array}$ \\
Kain Katun & $\begin{array}{l}\text { Baju setelan, jilbab, } \\
\text { masker, } \\
\text { dasaran }\end{array}$ \\
Kain kanvas \\
Kulit & $\begin{array}{l}\text { Tas, totebag } \\
\text { Tas kondangan, tas } \\
\text { laptop }\end{array}$ \\
\hline
\end{tabular}

Untuk pewarnaan, pengrajin Patera eco print lebih cenderung menggunakan bahanbahan pewarnaan yang alami dibanding dengan penggunaan bahan pewarnaan yang bersifat kimiawi, seperti naptol. Bahan-bahan pewarnaan alami didapatkan sekitar daerah Kota Palembang, selain itu bahan pewarnaan alami yang digunakan merupakan hasil tanaman sendiri, seperti daun jarak. Kelebihan penggunaan pewarna alami juga juga tidak merusak lingkungan, sehingga hasil dari sisasisa pewarnaan yang digunakan aman bagi masyarakat sekitar. 
Berikut adalah jenis-jenis bahan pewarnaan alami yang digunakan oleh Patera ecoprint.

Tabel 2. Jenis-jenis Bahan Pewarnaan Alami

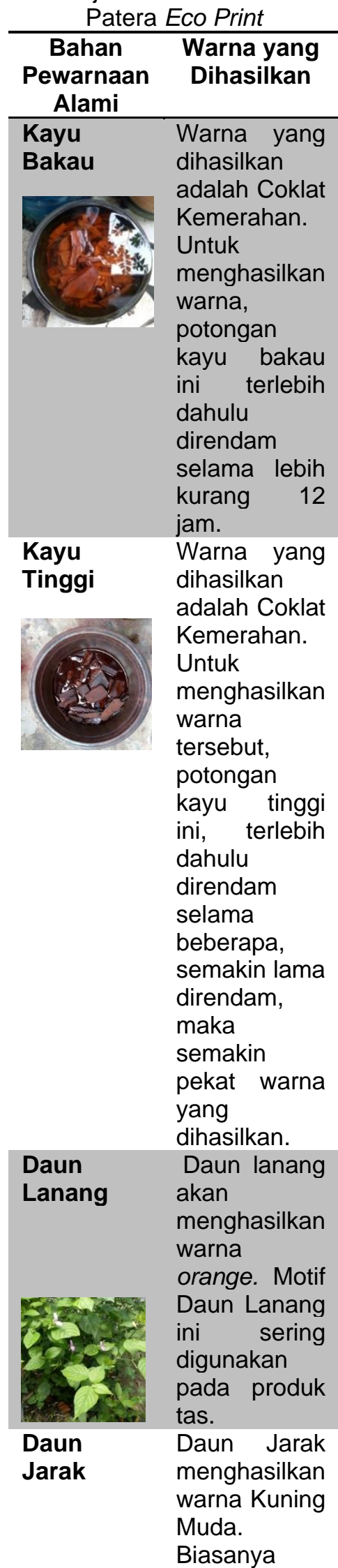

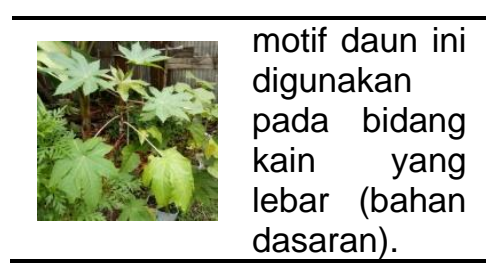

\section{Proses Produksi}

Kegiatan produksi kain eco print melalui beberapa tahapan, diantaranya adalah:

1. Memilih bahan kain yang akan digunakan sebagai bahan dasar untuk eco print

2. Merendam kain dalam pewarna alami. Proses perendaman ini dilakukan selama lebih kurang 12 jam (satu hari satu malam) agar dapat menghasilkan warna yang diinginkan.

3. Mengelompokkan beberapa jenis daun yang akan digunakan sebagai motif pada kain.

4. Menata dan menyusun pola motif dari daun-daun yang sebelumnya telah dipersiapkan. Pola motif daun yang diimplementasikan pada kain disusun dengan pola acak dan pola teratur.

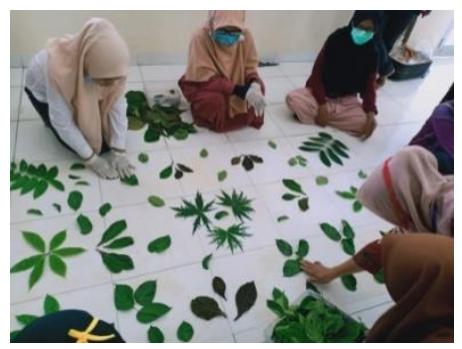

Gambar 5. proses eksplorasi penataan motif dengan kombinasi beberapa jenis daun.

5. (foto: Muhsin Ilhaq).Penggulungan kain. Proses ini setelah daun-daun ditata pada permukaan kain yang telah diwarnai. Kain tersebut digulung dengan menggunakan kayu bulat, kemudian diikat dengan tali rapia agar pola motif daun yang telah ditata tidak bergeser.

6. Tahap pengukusan. Tahap ini merupakan proses akhir. Tahap ini bertujuan untuk memindahkan motif-motif dari daun ke permukaan kain. 


\section{Produk-Produk Patera Eco Print}

Adapun jenis-jenis produk yang dihasil oleh Patera Eco Print adalah

1. Tas Laptop

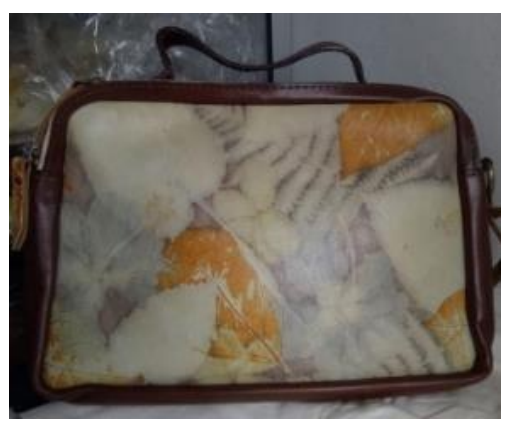

Gambar 6. Salah satu produk Patera Eco Print dengan bahan dasar kulit.

2. Baju

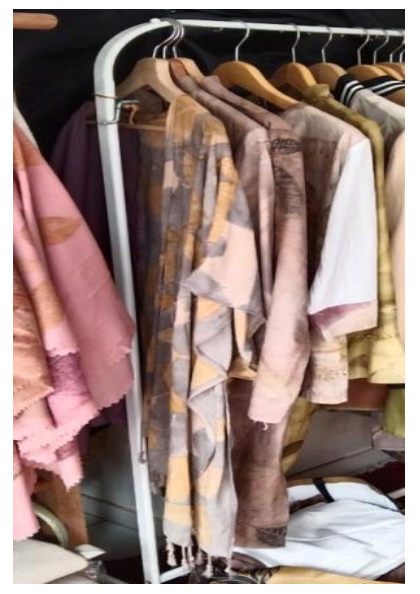

Gambar 7. Produk-produk baju yang dihasilkan Patera Eco Print dengan bahan kain katun.

3. Kain Dasaran

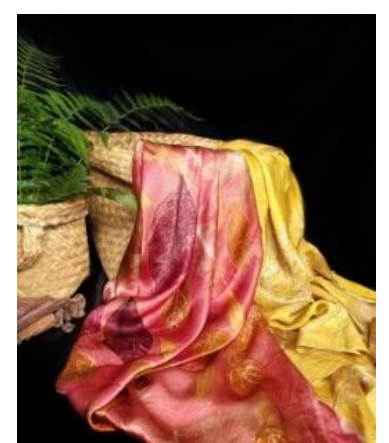

Gambar 8. Produk dasaran kain Patera Eco Print dengan bahan dasar kain sutera

\section{Gambaran IPTEK}

1. Dapat menciptakan inovasi-inovasi produk yang kreatif.
Volume 4, Nomor 2., April 2021. p-ISSN : 2614-5251 e-ISSN : 2614-526X

2. Memberi pemahaman tentang proses dan metode pengembangan desain desain produk sebagai bentuk pengayaan terhadap jenis-jenis produk yang ada, sehingga dapat menciptakan peluang pasar.

3. Memberikan pemahaman dan wawasan terhadap mitra sasaran tentang pentingnya media grafis ataupun media komunikasi visual sebagai aspek yang penting dalam membangun brand produk dan usaha, agar dapat kenali oleh masyarakat luas sebagai calon konsumen, baik secara konvensional maupun secara online.

\section{SIMPULAN DAN SARAN}

Kegiatan pelatihan innovasi dan pengembangan desain produk Patera Eco Print terlaksana sesuai dengan jadwal dan tahapantahapan pelatihan yang telah disusun secara bersama. Pelatihan ini menghasilkan berbagai desain produk yang baru, seperti tas laptop, baju kemeja, dan tote bag. Di samping itu pelatihan ini juga telah memberikan wawasan dan pemahaman tentang bagaimana membuat desain produk dan pengembangannya sehingga terciptanya inovasi pada produk tersebut. kegiatan ini tidak hanya memberikan pengalaman terhadap mitra Patera Eco Print, sebaliknya kegiatan ini juga telah memberikan pengalaman bagi nara sumber sehingga terciptanya kolaborasi antara akademis dan non akademis. Adapun saran untuk mitra Patera Eco Print, diharapkan agar selalu memberikan inovasi-inovasi produk yang baru agar dapat bersaing dengan produk yang sejeni baik skala lokal, regional, nasional, maupun internasional. Diharapkan juga kepada mitra Patera Eco Print agar dapat memanfaatkan media sosial secara maksimal untuk promosi dan pemasaran produk. Dengan demikan diharapkan mitra Patera Eco Print dapat lebih maju dan menjadi bagian industri kreatif yang produktif.

\section{UCAPAN TERIMAKASIH} kepada:

Ucapan terima kasih disampaikan

1. Pihak Universitas Indo global Mandiri, dalam hal ini adalah LP2MKPB yang telah memfasilitasi kegiatan ini

2. Pihak Mitra Patera Eco print yang telah bersedia menjadi mitra dalam pelatihan ini, semoga kegiatan ini membawa manfaat yang besar bagi kemajuan Pater a Eco Print.

3. Para narasumber yang telah bersedia untuk mentransferkan ilmu pengetahuan dan keterampilannya untuk mitra Patera 
Eco Print, semoga ini menjadi amal jariah untuk kemajuan Patera Eco Print sebagai bagian dari industri kreatif.

4. SELAPARANG. Jurnal Pengabdian Masyarakat Berkemajuan, yang telah bersedia untuk menerbitkan artikel Pengabdian Kepada Masyarakat ini, semoga artikel ini dapat bermanfaat bagi insan akademik dan masyarakat pada umumnya.

\section{DAFTAR RUJUKAN}

Hendriyana, H. (2019). Rupa Dasar Nirmana (Giovanny (ed.)). Andi.

Herlina, M. S., Dartono, F. A., \& Setyawan. (2018). Eksplorasi Eco Printing Untuk Produk Sustainable Fashion. Ornamen Jurnal Kriya Seni ISI Surakarta, 15(2), 118-130. https://jurnal.isiska.ac.id/index.php/ornamen/article/view/ 2540/2317

Mubarat, Husni., M. P. (2020). Pelatihan Kerajinan Bambu di Desa Keluru Kabupaten Kerinci menuju Industri Kreatif. Abdimas Mahakam Journal, 4(02), 217226.

Nyoman Kutha Ratna. (2010). Metodologi Penelitian Kajian Budaya dan IImu Sosial Humaniora pada Umumnya (1st ed.). pustaka Pelajar.

Yahya. (2016). No Title (yahya (ed.); 1st ed.). 